\title{
Antimicrobial Activity of Essential Oils from Pimenta pseudocaryophyllus and Tynanthus micranthus
}

\author{
Dayana Lacerda Custódio ${ }^{1}$, Rafaela Pinheiro Burgo ${ }^{2}$, Bárbara Moriel $^{3}$, Aneli de Melo \\ Barbosa $^{4}$, Maria Ines Rezende ${ }^{4}$, Juliana Feijó de Souza Daniel ${ }^{2}$, Jurandir Pereira Pinto ${ }^{2}$, \\ Edmilson Bianchini ${ }^{1}$ and Terezinha de Jesus Faria ${ }^{2 *}$ \\ ${ }^{I}$ Departamento de Biologia Animal e Vegetal; Universidade Estadual de Londrina; Londrina - PR - Brasil. \\ ${ }^{2}$ Departamento de Química; Universidade Estadual de Londrina; Londrina - PR - Brasil. ${ }^{3}$ Departamento de \\ Microbiologia; Universidade Estadual de Londrina; Londrina - PR - Brasil. ${ }^{4}$ Departamento de Bioquímica e \\ Biotecnologia; Universidade Estadual de Londrina; C. P.: 6001; 86051-990; Londrina - PR - Brasil
}

\begin{abstract}
The present study describes the chemical composition and antimicrobial activity of essential oils obtained by hydrodistillation from the leaves of Pimenta pseudocaryophyllus $(1.0 \% \mathrm{w} / \mathrm{w})$ and Tynanthus micranthus $(1.1 \% \mathrm{w} / \mathrm{w})$. GC and GC/MS analysis demonstrated that eugenol was the only component in the T. micranthus essential oil (99.9\%) and the major component in the P. pseudocaryophyllus essential oil (92.59\%), which also presented methyleugenol, terpinen-4-ol, o-cymene and (E)-caryophyllene, among others. Both the oils presented antimicrobial activity against bacteria, yeast and filamentous fungi tested.The Bioautography test revealed that eugenol was the bioactive component in both the oils against Cladosporium herbarum. This is the first report about the T. micranthus essential oil, and the antifungal activity of $\mathrm{P}$. pseudocaryophyllus. The results confirmed the potential of eugenolrich essential oils not only as a source of flavor compounds, but also of use as antimicrobial agent in agriculture and in pharmaceutical and food products.
\end{abstract}

Key words: Pimenta pseudocaryophyllus, Tynanthus micranthus, essential oil, antimicrobial activity

\section{INTRODUCTION}

Synthetic pesticides have been used for decades to prevent, control or eradicate the plant diseases. In spite of their efficiency, these compounds may disrupt the equilibrium of ecosystems leading to health and environmental problems. The adverse environmental impact caused by the first developed fungicides has resulted in the development of alternative methods for the pest and disease control in agriculture and forestry (Lee et al., 2008). Such issues have created a significant market opportunity for natural products, including the essential oils. These substances, obtained from the aromatic plants by hydrodistillation, have been traditionally used to protect the grains and vegetables during the storage (Murray, 2000), and their potential use as alternative medicine for the treatment of several infectious diseases have also been studied (Prabuseenivasan et al., 2006). Several studies have been carried out on the application of aromatic plants, not only in food

*Author for correspondence: tjfaria@uel.br 
manufacturing but also in pharmaceutical and cosmetic formulations (Guillén and Manzanos, 1996).

Eugenol, 4-allyl-2-methoxy-phenol, is found in the essential oils from the aromatic plants such as Eugenia caryophillis (clove), Cinnamomum verum (cinnamon) and Ocimum gratissimum (alfavacão) (Ali et al., 2005), and many studies have discussed their activities against several pathogenic bacteria and fungi (Shapiro et al.,, 1994; Ali et al., 2005; Faria et al., 2006). Recently, the applications of natural and synthetic eugenol and essential oils from E. caryophyllata, Pimenta officinalis and Cinamomum zeylanicum on the prevention and treatment of animal diseases caused by bacteria, fungi, and parasites have been patented (Vojin, 2005). In addition to these activities, eugenol has nematicide, insecticide and allelopathic effects, which inhibits the germination of various species (Mazzafera, 2003).

Eugenol has been used commercially as analgesic and skin disinfectants in dentistry, in the manufacturing of toothpastes, perfume and soaps, in histological clarification techniques, and as raw material to obtain vanillin, a compound widely used by the food industry. This compound has also been studied as raw material for the synthesis of biologically active natural products (Costa, 2000).

$P$. pseudocaryophyllus (Gomes) L. R. Landrum and Tynanthus micranthus Corr.Méllo ex K.Schum. are native species of the Brazilian flora with a clove-like taste. T. micranthus (Bignoniaceae) is used by popular medicine in the production of tea used in the healing process of colds, but there are no studies of this species. Data on Tynanthus genus are scarce; however, a study on the bark of $T$. panurensis reported the occurrence of verbascoside, isoverbascoside, leucosceptoside, and flavonoid, namely katchimoside and phenylpropanoid glycoside (Plaza et al.,2005), while a phytochemical investigation on $T$. fasciculatus led to the isolation of $\beta$-sitosterol- $\beta$-D-glucoside (Vilegas et al., 1993), coumarin, stigmasterol and melilotic acid derivative (Vilegas et al.,1995). The Pimenta genus (Myrtaceae) has been widely studied due to its biological properties, which include antimicrobial, anti-inflammatory, antinociceptive and hypotensive activities, among others (Fernández et al.,2001; García et al., 2004; Suárez et al.,1997). P. pseudocaryphyllus is used as flavor enhancer in the cooking and in the preparation of tea. The species presents an essential oil in the leaves whose composition seems to vary depending of the origin of the specimen (Lima et al., 2006; Sakita et al., 1994).

In continuation to the search of essential oils rich in eugenol, in order to test its antimicrobial effects, the essential oils of Pimenta pseudocaryophyllus and Tynanthus micranthus collected in São Jerônimo da Serra and Londrina, respectively, were analyzed. The Essential oils extracted from the fresh leaves of the plants were evaluated according to yield, chemical composition and activity against pathogenic bacteria and fungi, some of which were phytopathogenic and bringing losses to the agriculture.

\section{MATERIALS AND METHODS}

\section{Plant material}

The leaves of $P$. pseudocaryophyllus were collected in the county of São Jerônimo da Serra (Paraná, Brazil) in December/2007. The leaves of T. micranthus were collected in April/2008 at Universidade Estadual de Londrina Department of Agronomy - UEL (Londrina, Paraná, Brazil). Voucher specimens of $P$. pseudocaryophyllus and T. micranthus were prepared, identified, and deposited at the Universidade Estadual de Londrina Herbarium (FUEL 43025 and FUEL 45005, respectively).

\section{Essential oil extraction}

The essential oils were obtained from the fresh leaves $(80 \mathrm{~g})$ of both the species by hydrodistillation in a Clevenger apparatus for two hours. The distillate was extracted with dichloromethane $(4 \times 70 \mathrm{~mL})$. The organic phase was dried over anhydrous sodium sulphate, filtered and concentrated under reduced pressure. The method yielded $0.8 \mathrm{~g}$ of $P$. pseudocaryophyllus oil and $0.9 \mathrm{~g}$ of T. micranthus oil. The two oils were solubilized in dichloromethane for gas chromatography and mass spectrometry analysis.

\section{GC and GC/MS analysis}

The analysis of the volatile compounds were carried out on a Shimadzu gas chromatography model GC-17A, equipped with a flame ionization detector (FID) and a DB-5 (JandW Scientific) capillary column $(30 \mathrm{~m}$ long, $0.25 \mathrm{~mm}$ internal diameter, $0.25 \mu \mathrm{m}$ film thickness). The programmed temperature began at $60{ }^{\circ} \mathrm{C}$ and increased by $7{ }^{\circ} \mathrm{C} / \mathrm{min}$ up to $320{ }^{\circ} \mathrm{C}(5 \mathrm{~min})$. 
Injector and detector temperatures were 220 and $300{ }^{\circ} \mathrm{C}$, respectively. Nitrogen was used as carrier, at a flow rate of $1.2 \mathrm{~mL} / \mathrm{min}$. The diluted samples (1:10 in dichloromethane, $\mathrm{v} / \mathrm{v})$ of $2.0 \mu \mathrm{L}$ were injected and the split ratio was 1:20. The area of the GC peak was used for quantitative determination.

GC/MS-capillary gas chromatography was performed in a Shimadzu chromatography coupled to a Shimadzu GC/MS-QP5000 using a DB-1 capillary column $(30 \mathrm{~m} \times 0.25 \mathrm{~mm}) 0.25 \mu \mathrm{m}$ film thickness. Injector and detector temperatures were 300 and $250{ }^{\circ} \mathrm{C}$, respectively. The carrier gas was helium at a flow rate of $1.2 \mathrm{~mL} / \mathrm{min}$, and the programmed temperature began at $60{ }^{\circ} \mathrm{C}$ and increased by $7{ }^{\circ} \mathrm{C} / \mathrm{min}$ up to $320{ }^{\circ} \mathrm{C}(5 \mathrm{~min})$. Mass spectra (electron impact) of the compounds were obtained using an ionization chamber at a temperature of $250{ }^{\circ} \mathrm{C}$.

\section{Identification of the oils constituents}

Oil components were identified by comparing their mass spectra with NIST98 (National Institute of Standards and Technology, Gaithersburg) mass spectral database and by comparing their GC retention indexes (RI), related to the retention time of a series of $n$-alkanes with linear interpolation, with those of literature data (Adams, 2007). Eugenol mass spectrum and retention time were compared with data from an authentic sample. Relative amount of individual component was performed on the basis of their GC peak areas.

\section{Antimicrobial activity}

Microbial strains

The microorganisms used in the antimicrobial and antifungal tests were: (i) three clinically isolated yeast from the UEL School Hospital: Candida albicans, Candida krusei and Candida tropicalis; (ii) four referenced strains: two Gram-positive bacteria: Bacillus subtilis (ATCC 8272) and Staphyloccocus aureus (25923), two Gramnegative bacteria: Pseudomonas aeruginosa (27853) and Escherichia coli (25922) and (iii) five filamentous fungi cultures from the Biochemistry Laboratory collection of the Universidade Estadual de Londrina, Brazil: Botryosphaeria rhodina, Botryosphaeria ribis, Claudosporium herbarum, Fusarium verticillioides and Lasiodiplodia theobromeae. The strains were grown on a Mueller-Hinton agar (MHA) for bacteria, a Sabouraud Dextrose Agar (SDA) for yeasts and a Potato Dextrose Agar for moulds.

\section{Preparation of inocula}

\section{Bacteria}

The strains preserved in the Müeler-Hinton agar at $4{ }^{\circ} \mathrm{C}$ were revived in Müeller-Hinton solution and incubated at $37 \pm 2{ }^{\circ} \mathrm{C}$ during $18-24 \mathrm{~h}$. The inoculums for the tests consisted from a suspension of the cells $\left(10^{8} \mathrm{UFC} / \mathrm{mL}\right.$ using the Mc Farland scale).

\section{Yeast}

The strains preserved in the Sabouraud agar at $4{ }^{\circ} \mathrm{C}$ were revived in Sabouraud solution and incubated at $30 \pm 1{ }^{\circ} \mathrm{C}$ for $24-48 \mathrm{~h}$. The inoculums for the tests consisted from a suspension of cells containing $10^{8} \mathrm{UFC} / \mathrm{mL}$.

\section{Filamentous fungi}

The filamentous fungi preserved in the Potato Dextrose Agar at $4{ }^{\circ} \mathrm{C}$ were revived in Potato Dextrose Agar and incubated at $28 \pm 2{ }^{\circ} \mathrm{C}$ for $5-10$ days. The plugs of $7 \mathrm{~mm}$ diameter were used as inocula.

\section{Antimicrobial screening}

Three techniques were used to test the microbial activity for the two oils: the TLC bioautography (Homans and Funchs, 1970), the agar diffusion (Quiroga et al.,2001) and the microdilution test (NCCLS document M7-A6, 2003).

\section{TLC bioautography}

The essential oils were applied $(0.25 \mathrm{mg} / \mathrm{spot})$ on the teo TLC plates and developed in a hexane/ dichloromethane mixture (50\%). One plate was used as the reference chromatogram, and the other for the bioautography. A spore suspension of $C$. herbarum was sprayed over the developed TLC plate, which was incubated at $28{ }^{\circ} \mathrm{C}$ under humid conditions for three days (Homans and Funchs, 1970). The observed inhibitory zones were then correlated with the spots seen on the TLC plate used as the reference chromatogram and visualized under the UV light at $254 \mathrm{~nm}$.

\section{Agar dilution}

The in vitro biological activity of the oils against the filamentous fungi was assessed according to their hyphal radial growth rate. Different volumes of both the oils were diluted in ethyl acetate and poured into Erlenmeyer flasks containing $16 \mathrm{~mL}$ hot sterilized growth medium (PDA). Afterwards it was thoroughly mixed and poured into Petri 
dishes $(60 \times 15 \mathrm{~mm})$. For control tests, the plates were prepared with ethyl acetate as solvent control, a plate with Captan (N[(trichloromethyl)thio]-4-cyclohexene-1,2-

dicarboximide), as negative growth control, and a plate containing only PDA as positive growth control. The assay was performed by placing a 7 $\mathrm{mm}$ diameter plug of growing media onto the centre of a Petri dish containing the oil in the medium. This plug was taken from 5-10 days of culture. The plates were incubated for 5-10 days, to confirm the growth in the positive growth control plate.

Determination of the minimum inhibitory concentration (MIC)

A dilution agar method was used to determine the MIC. A 96-well plastic microplate was used. Each well contained $100 \mu \mathrm{L}$ of Mueller-Hinton for the bacteria and Sabouraud for the yeasts, plus a fixed volume of serially diluted oil plants, with concentrations of 0.5 to $66 \mu \mathrm{L} / \mathrm{mL}$. Each well was incubated with a $100 \mu \mathrm{L}$ aliquot of the inoculum. Incubations were performed at $30{ }^{\circ} \mathrm{C}$ for $24 \mathrm{~h}$ for the bacteria and $25^{\circ} \mathrm{C}$ for $48 \mathrm{~h}$ for the yeast. Next, $50 \mu \mathrm{L}$ of aqueous solution of TTC (Triphenyl Tetrazolium Chloride) at $0.5 \%$ was added and the microplate was incubated for $3 \mathrm{~h}$ at the aforementioned temperature. The MIC was defined as the lowest concentration of oil that inhibited the microorganism growth.

\section{RESULTS AND DISCUSSION}

\section{Chemical composition of oils}

Essential oils yields were of 1.0 and $1.1 \%$ from $P$. pseudocaryophyllus and T. micranthus, respectively. The analysis revealed eugenol as the main constituent in $P$. pseudocaryophyllus oil (92.59\%) and as the only component in $T$. micranthus oil (99.9\%). The identity of the substance was confirmed through the comparison of its mass spectrum and retention index with an eugenol authentic sample. Results obtained in this first report on the composition of $T$. micranthus essential oil was similar to that obtained for $T$. panurensis cortex, which presented eugenol as the only constituent (99.9\%) (Leclercq et al., 2000). The $P$. pseudocaryophyllus essential oil presented other components such as methyleugenol, terpinen-4-ol, $o$-cymene and (E)-caryophyllene, identified by the comparison of its mass spectrum and the Kowats Index with literature data (Adams, 2007).

Studies on the $P$. pseudocaryophyllus essential oil revealed different oil compositions. The analysis of the P. pseudocaryophyllus oil collected in Campos do Jordão, São Paulo state, showed the geranial $(34.26 \%)$ and neral $(27.85 \%)$ as main constituents, among others (Sakita et al.,1994). However, different results were obtained in the studies with the two specimens collected from other locations in the state of São Paulo (Lima et al., 2006). The essential oil in a specimen collected from Cardoso Island also presented eugenol as its main component (71.9\%), while the essential oil of the specimen collected from Paranapiacaba county presented the 4-methyleugenol (94.6\%) as its main component.

Other species of the Pimenta also contain essential oils. P. dioica leaves provided an essential oil with eugenol as its main constituent (77.9\%) (Marongiu et al., 2005). The $P$. racemosa var. terebinthina essential oil presented $\alpha$ - terpineol acetate (37\%), $\alpha$ - terpineol (20\%) and methoxyeugenol (12.6\%), as constituents, differently from $P$. racemosa var. grisea essential oil, which contains 4methoxyisoeugenol (75.2\%) and 4methoxyeugenol (4.5\%) (Garcia et al.,2002).

\section{Antimicrobial activity}

In the TLC bioautography, both the essential oils presented a spot $(\mathrm{Rf}=0.29)$ with strong activity against $C$. herbarum. The active compounds of both the oils were isolated by the preparative thinlayer chromatography and identified as eugenol by GC/MS and by comparison with authentic sample. Although the two oils presented the same main compound (eugenol) results were different in the tests. In the dilution agar test with filamentous fungi, the T. micranthus oil acted better than the $P$. pseudocaryophyllus oil. Both the oils showed good inhibition at the highest concentration. The $T$. micranthus oil inhibited more than $80 \%$ of the mycelial growth for B. ribis and 40 to $80 \%$ of the growth of other filamentous fungi tested. The $P$. pseudocaryophyllus oil presented an inhibition of 40 to $80 \%$ of the micelial growth for B. rhodina and $F$. verticillioides and up to $40 \%$ of inhibition against $B$. ribis and $L$. theobrome (Table 1). However, the microdilution test with bacteria and yeasts showed different results. The $P$. pseudocaryophyllus oil showed an equal or lower MIC than the T. micranthus oil for all the bacteria and yeasts tested (Table 2). 
Table 1 - Percentage of inhibition promoted by P. pseudocaryophyllus and T. micranthus essential oils on the growth of fungi. The inhibition was reported as (-) <10\% growth inhibition, ( \pm ) between 10 and $20 \%$, (+) between 20 and $40 \%,(++)$ between 40 and $80 \%$, and $(+++)>80 \%$.

\begin{tabular}{|c|c|c|c|c|c|c|c|c|c|c|c|c|}
\hline \multirow{3}{*}{ Filamentous fungi } & \multicolumn{6}{|c|}{ P.pseudocaryophyllus oil } & \multicolumn{6}{|c|}{ T. micranthus oil } \\
\hline & \multicolumn{6}{|c|}{ Concentrations (mg/plate) } & \multicolumn{6}{|c|}{ Concentrations (mg/plate) } \\
\hline & 4.0 & 2.0 & 1.5 & 1.0 & 0.5 & 0.25 & 4.0 & 2.0 & 1.5 & 1.0 & 0.5 & 0.25 \\
\hline Botryosphaeria rhodina & ++ & + & + & + & - & - & ++ & + & \pm & - & - & - \\
\hline Botryosphaeria ribis & \pm & - & - & - & - & - & +++ & + & - & - & - & - \\
\hline Fusarium verticillioides & ++ & + & + & \pm & - & - & ++ & + & + & + & - & - \\
\hline Lasiodiplodia theobromeae & + & - & - & - & - & - & ++ & \pm & \pm & - & - & - \\
\hline
\end{tabular}

Table 2 - Minimum inhibitory concentration (MIC) of P. pseudocaryophyllus and T. micranthus essential oils.

\begin{tabular}{|c|c|c|}
\hline Microrganism & MIC $(\mu \mathrm{L} / \mathrm{mL})$ P. pseudocaryophyllus & MIC $(\mu \mathrm{L} / \mathrm{mL}) T$. micranthus \\
\hline Bacillus subtilis & 17 & 17 \\
\hline Staphylococcus aureus & 17 & 33 \\
\hline Pseudomonas aeruginosa & 66 & 66 \\
\hline Escherichia coli & 17 & 17 \\
\hline Candida albicans & 4 & 17 \\
\hline Cândida krusei & 4 & 17 \\
\hline
\end{tabular}

Among the tested bacteria, $P$. aeruginosa was the most resistant and the MIC for both the oils showed high concentration on the microplate. This concentration was bactericidal for the $P$. pseudocaryophyllus oil and bacteriostatic for the $T$. micranthus. The same MIC was found for the $B$. subtilis and E. coli, and was bactericidal for the former and bacteriostatic for the latter for both the oils. For S. aureus, the P. pseudocaryophyllus oil presented better activity than the $T$. micranthus oil, and both the oils presented bactericidal activity.

Yeast tests showed that the MICs for both the oils were fungicidal; however, the $P$. pseudocaryophyllus oil presented the lower MICs than the $T$. micranthus oil, showing good activity against the yeasts tested.

There are no reports in the literature on the antifungal activity of $P$. pseudocaryophyllus. However, Lima et al. (2006) have determined the antibacterial activity of the essential oils in two $P$. pseudocaryophyllus, collected from the Cardoso Island and in Paranapiacaba, using the microdilution method. The eugenol-rich specimen from Cardoso Island presented the best results against $E$. coli while against $C$. albicans, the best result came from a specimen collected from the Paranapicaba County, rich in 4-methyleugenol. Both the specimens showed similar results against $P$. aeruginosa and $S$. aureus. The differences in the sensitivity observed were attributed to the different chemical composition: the presence of 4- methyleugenol increased its toxic effects against $S$. aureus and $C$. albicans and decreased the toxicity against $E$. coli. The presence of estragole might have contributed to the results by synergism with 4-methyleugenol.

There are reports that the $P$. racemosa var. grisea essential oil shows a more pronounced activity than the $P$. racemosa var. terebinthina oil against Gram (+) and Gram (-) bacteria. The antibacterial effect exhibited by $P$. racemosa var. grisea could be attributed to the presence of 4-methoxyeugenol $(75.23 \%)$ and 4-methoxyeugenol $(4.52 \%)$ in the oil. The antibacterial effect presented by the essential oil from the $P$. racemosa var. terebinthina, compared to the standards used or with other volatile oils as pine, cinnamon and thyme, was attributed to the terpene nature of the main components, $\alpha$-terpineol acetate $(27 \%)$ and $\alpha$-terpineol (20\%), of this oil (Saenz et al.,2004).

In the present study, the highest activity of $T$. micranthus essential oil against filamentous fungi could be attributed to the high concentration of eugenol present in this oil (99.9\%), when compared to the content of eugenol present in the P. pseudocaryophyllus essential oil (92.59\%). Furthermore, the slight differences of activity between the two oils tested suggested that these activities must also be related to other components present in the $P$. pseudocaryophyllus essential oil than in eugenol. 


\section{CONCLUSIONS}

In this study, the chemical composition and antimicrobial activity of the essential oils from $T$. micranthus and $P$. pseudocaryophyllus were investigated. Both the oils were obtained in good yield ( 1\%). The GC and GC/MS analysis demonstrated that eugenol was the only component in the $T$. micranthus essential oil (99.9\%) and the major component in the $P$. pseudocaryophyllus essential oil (92.59\%), which also presented methyleugenol, terpinen-4-ol, $o$ cymene and $(E)$-caryophyllene, among others. The chemical composition of $P$. pseudocaryophyllus essential oil differed from those reported earlier. The pronounced activity against the bacteria, yeast and moulds demonstrated the antimicrobial potential of eugenol-rich essential oils and suggested the possibility of using these oils as natural food preservative and in vivo studies to develop the antimicrobials for human, animal and plants pathogens.

\section{ACKNOWLEDGEMENTS}

The authors are grateful to Conselho Nacional de Desenvolvimento Científico e Tecnológico (CNPq) for financial support and to Dr. Ana Odete Santos for identifying the plants.

\section{RESUMO}

O presente trabalho descreve a análise da composição química e a avaliação da atividade antimicrobiana dos óleos essenciais obtidos por hidrodestilação das folhas de Pimenta pseudocaryophyllus $(1.0 \% \mathrm{~m} / \mathrm{m})$ e de Tynanthus micranthus $(1.1 \% \mathrm{~m} / \mathrm{m})$. As análises por $\mathrm{CG}$ e CG-EM demonstraram que o óleo essencial de $P$. pseudocaryophyllus apresenta o eugenol como componente principal ( $92.6 \%$ ), além de outros constituintes como methyleugenol, tepinen-4-ol, O-cimeno e (E)-cariofileno. $\mathrm{O}$ óleo de $T$. micranthus contém o eugenol como único constituinte (99.9\%). Ambos os óleos apresentaram atividade contra bactérias, leveduras e fungos filamentosos. O teste de bioautografia revelou o eugenol como a substância responsável pela atividade contra o Cladosporium herbarum dos óleos das duas espécies. Este é o primeiro estudo sobre o óleo essencial de $T$. micranthus e o primeiro relato sobre a atividade antifúngica do óleo essencial de $P$. pseudocaryophyllus. Os resultados obtidos confirmaram o potencial de óleos essenciais ricos em eugenol para uso como agentes antimicrobianos na agricultura e na preparação de produtos alimentícios e farmacêuticos.

\section{REFERENCES}

Adams, R. P. (2007), Identification of essential oil components by gas chromatography/ mass spectrometry, $4^{\text {th }}$ ed., Allured Publishing Corporation, Carol Stream.

Ali, S. M., Khan, A. A., Ahmed, I., Musaddiq, M., Ahmed, K. S., Polasa, H., Rao, L. V., Habibullah, C. M., Sechi, L. A. and Ahmed, N. (2005), Antimicrobial activities of eugenol and cinnamaldehyde against the human pathogen Heliobacter pylori. Ann Clin Microbiol Antimicrobials, 4, 20-26.

Costa, P. R. R. (2000), Safrol e eugenol: Estudo da reatividade e uso em síntese de produtos naturais biologicamente ativos e seus derivados. Quim Nova, 23, 23-28.

Faria, T. J.; Ferreira, R. S.; Yassumoto, L.; Souza, J. R. P.; Ishikawa, N. K.; Barbosa, A. M. (2006), Antifungal Activity of Essential Oil Isolated from Ocimum gratissimum L. (eugenol chemotype) against Phytopathogenic Fungi. Braz Arch Biol Techn, 49, 867-871.

Fernández, A., Alvarez, A., García, M. D., and Saénz, M. T. (2001), Anti-inflamatory effect of Pimenta racemosa var. ozua and isolation of the triterpene lupeol, IL Fármaco, 56, 335-338.

Garcia, D., Alvarez, A., Tornos, P., Fernández, A., and Saenz, M. T. (2002), Gas Chromatographic-Mass Spectrometry Study of the Essential Oils of Pimenta racemosa var. terebinthina and $P$. racemosa var. grisea. Z. Naturforsch, 57c, 449-451.

García, M. D., Fernández, M. A., Alvarez, A., and Saenz, M. T. (2004), Antinociceptive and antiinflamatory effect of the aqueous extract from leaves of Pimenta racemosa var. ozua (Myrtaceae). J Ethnopharmacol, 91, 69-73.

Guillén, M. D., and Manzanos, M. J. (1996), A study of several parts of the plant Foeniculum vulgare as a source of compounds with industrial interest. Food Res Int, 29, 85-88.

Homans, A. L., and Funchs, A. (1970), Direct bioautography on thin - layer chromatograms as a method for detecting fungitoxic substances. $J$ Chromatogr, 51, $327-329$. 
Lee, Y., Kim, J., Shin, S., Lee, S., and Park, I. (2008), Antifungal activity of Myrtaceae essential oils and their components against three phytopathogenic fungi. Flavour Frag J, 23, 23-28.

Leclercq, P. A., Delgado, H. S., Garcia, J., Hidalgo, J. E., Cerruttti, T., Mestanza, M., Rios, F., Nina, E., Nonato, L., Alvarado, R., and Menendez, R. (2000), Aromatic plant oils of the Peruvian Amazon. Part 2. Cymbopogon citratus (DC) Stapf., Renealmia sp., Hyptis recurvata Point. and Tynanthus panurensis (Bur.). J Essent Oil Res, 12, 14-18.

Lima, M. E. L., Cordeiro, I., Young, M. C. M., Sobra, M. E. G., and Moreno, P. R. H. (2006), Antimicrobial activity of the essential oil from two specimens of Pimenta pseudocaryophyllus (Gomes) L. R. Landrum (Myrtaceae) native from São Paulo State - Brazil. Pharmacol on line, 3, 589-593.

Marongiu, B., Piras, A, and Porcedda, S. (2005), Comparative Analysis of Supercritical $\mathrm{CO}_{2}$ Extract and Oil of Pimenta dioica Leaves. J Essent Oil Res, 17, 530-532.

Mazzafera, P. (2003), Efeito alelopático do extrato alcoólico do cravo-da-índia e eugenol. Rev. Bras. Bot., 26, 231-238.

Murray, I. (2000), Plant essential oils for pest and disease management. Crop Portection, 19, 603-608.

NCCLS. (2003). Methods for Dilution Antimicrobial Susceptibility Tests for Bacteria That Grow Aerobically, $6^{\text {th }}$ ed. NCCLS document M7-A6 (ISBN 1-56238-486-4). Wayne.

Plaza, A., Montoro P., Benavides, A. Pizza C., Piacente, S. (2005), Phenylpropanoid glycosides from Tynanthus panurensis: characterization and LC-MS quantitative analysis. J Agr Food Chem., 53, 28532858.

Prabuseenivasan, S., Jayakumar, M., and Ignacimuthu, S. (2006), In Vitro antibacterial activity of some plant essential oils. BMC Complementary and Alternative Medicine, 6, 39-46.

Quiroga, E. N., Sampietro, A. R., and Vattuone, M. A. (2001), Screening antifungal activities of selected medicinal plants. J Ethnopharmacol, 74, 89-96.
Saenz, M. T., Tornos, M. P., Alvarez, A. Fernandez, M. A., and García, M. D. (2004), Antibacterial activity of Essentials oils of $P$. racemosa var. terebinthina and Pimenta racemosa var. grisea. Fitoterapia, 75, 599602.

Sakita, M. N., Aguiar, O. T., Yatagai, M., and Igarashi, T. (1994), Óleo Essencial de Pimenta pseudocaryophyllus var. pseudocaryophyllus (Gomes) Landrum (Myrtaceae) I: cromatografia a gás/ espectrometria de massa (CG/EM). Rev. Inst. Flor., 6, 53-61.

Shapiro, S., Meier, A., and Guggenheim, B. (1994), The antimicrobial activity of essential oils and essential oil components towards oral bacteria. Oral Microbiol Immun, 9, 202-8.

Suárez, A., Ulate, G., and Ciccio, J. F. (1997), Cardiovascular effects of ethanolic and aqueous extracts of Pimenta dioica in Sprague- Dawley rats. $J$ Ethnopharmacol, 55,107- 111.

Vilegas, J. H. Y., Vilegas, W., Pozetti, G. L., and Llabres, G. (1993), Constituents of Brazilian medicinal plants.2. Constituents of Tynanthus fasciculatus. Fitoterapia, 64, 476.

Vilegas, W., Vilegas, J. H.Y., Pozetti, G. L., and Moreno, R. M. S. (1995), The chemistry of "cipócravo" Tynanthus fasciculatus. Rev Latinoam Quím., 23, 47-49.

Vojin, G. (2005), Application of natural and synthetic eugenol and essential oils from cloves, pimentos and cinnamon leaves for the prevention and treatment of animal diseases caused by bacteria, fungi and parasites. International Patent WO/2005/074965.

Received: August 13, 2009; Revised: December 14, 2009 Accepted: August 18, 2010 